\title{
Trends in Danish national PV programme
}

\section{Sørensen, Bent}

Published in:

Sixteenth European Photovoltaic Solar Energy Conference

Publication date:

2000

Document Version

Publisher's PDF, also known as Version of record

Citation for published version (APA):

Sørensen, B. (2000). Trends in Danish national PV programme. In H. Scheer (Ed.), Sixteenth European Photovoltaic Solar Energy Conference: proceedings of the international conference held in Glasgow, United Kingdom, 1-5 May 2000 (pp. 2805-2808). Earthscan.

\section{General rights}

Copyright and moral rights for the publications made accessible in the public portal are retained by the authors and/or other copyright owners and it is a condition of accessing publications that users recognise and abide by the legal requirements associated with these rights.

- Users may download and print one copy of any publication from the public portal for the purpose of private study or research.

- You may not further distribute the material or use it for any profit-making activity or commercial gain.

- You may freely distribute the URL identifying the publication in the public portal.

\section{Take down policy}

If you believe that this document breaches copyright please contact rucforsk@kb.dk providing details, and we will remove access to the work immediately and investigate your claim. 


\title{
TRENDS IN DANISH NATIONAL PV PROGRAMME
}

\author{
Bent Sørensen \\ Roskilde University, Institute of Mathematics and Physics, Energy \& Environment Group. \\ email: bes@ ruc.dk, www: http://mmf.ruc.dk/energy, fax +45 46743020 \\ P.O.Box 260, DK-4000 Roskilde, Denmark, Phone +45 46742028
}

\begin{abstract}
Developments in the focus of the Danish National PV Programme are presented and discussed, as an example of the considerations that a small country must make in order to obtain maximum dividend on its RD\&D spending.

Keywords: R\&D programme - 1: Photovoltaics - 2: Solar cells -3: Photo-electrochemical cells -4.
\end{abstract}

\section{INTRODUCTION}

The Danish national PV programme started in 1991, dthough scattered support for PV projects had materialised earlier, within existing programmes. The new support was through the Renewable Energy Development Programme ("UVE") of the Danish Energy Agency (spending 2-4 MDKK/y on PV), although the basic Energy Research Programme ("EFP") additionally did have a slot for PV. The early phase focussed upon individual demonstration and knowledge dissemination projects (Katic et al., 1994). Two new dimensions were added in late 1999, where considerations regarding system development have expanded the scope of the programme in the direction of research and development, while at the same time demanding a programme extension into the area of market stimulation. One is a new $\mathrm{PV}$ programme, adding $10 \mathrm{MDKK} / \mathrm{y}$ to the existing funds and demanding specific R\&D in the fields of novel devices, demonstration of building-integrated solutions, and basic information and quality assurance activities. The other is a recycling of energy taxes, first carried through in the electricity sector but being expanded to the gas sector, allowing $R \& D$ expenditures to be covered, if they are relevant for an energy transition strategy in tune with the official government planning (Danish Department of Energy, 1999). Industrial investments in building-integrated PV are supported by a $40 \%$ subsidy. In the future, the PV area may also carve itself a larger chunk of the basic research money ("EFP"), if promising new developments are materialising within the new programmes.

Historically, Denmark has contributed to crystalline silicon PV development, notably through the research performed at the Danish Technical University (see e.g. Leistiko, 1997). An offspring of this was a commercial cell production venture by the company "Solel", which, however, failed due to lack of market penetration. The problem was and is, that there is no significant niche market for photovoltaics in Denmark: Few vacation houses are so remote that they are not served by an electric power grid, interest in small-scale farm use is absent, and industrial "image greening" efforts have in Denmark been less willing to invest in building energy systems, compared to many other countries. Finally, public "showing the way" has been absent, as it is only this year (2000), that a suggestion of compulsory use of solar energy in public buildings (schools, etc.) is being introduced to the parliamentary decision process. Today, the Danish business scene as far as $\mathrm{PV}$ is concerned consists of a number of small companies selling modules based upon imported cells, or other derived products. Newcomers include solar thermal collector companies who faces dwindling profits for their current products due to insufficient market penetration (presumably due to lack of market backing - sales of solar thermal systems quadrupled during one year, where the gas companies offered fixed price, warranty-backed solar systems to their gas customers). Now the solar thermal producers look to $\mathrm{PV}$ as a possible rescue technology, because they see public funding as creating at least a demonstration product market. The other types of newcomers are companies with no previous experience in renewable energy, typically building element producers, seeing PV integrated into windows and facade elements as an interesting addition to their product lines. These companies are interesting, because they usually have achieved high market visibility for their products, but they still likely to need some time to appreciate the technical problems of a technology considerably more complex than what they have been accustomed to.
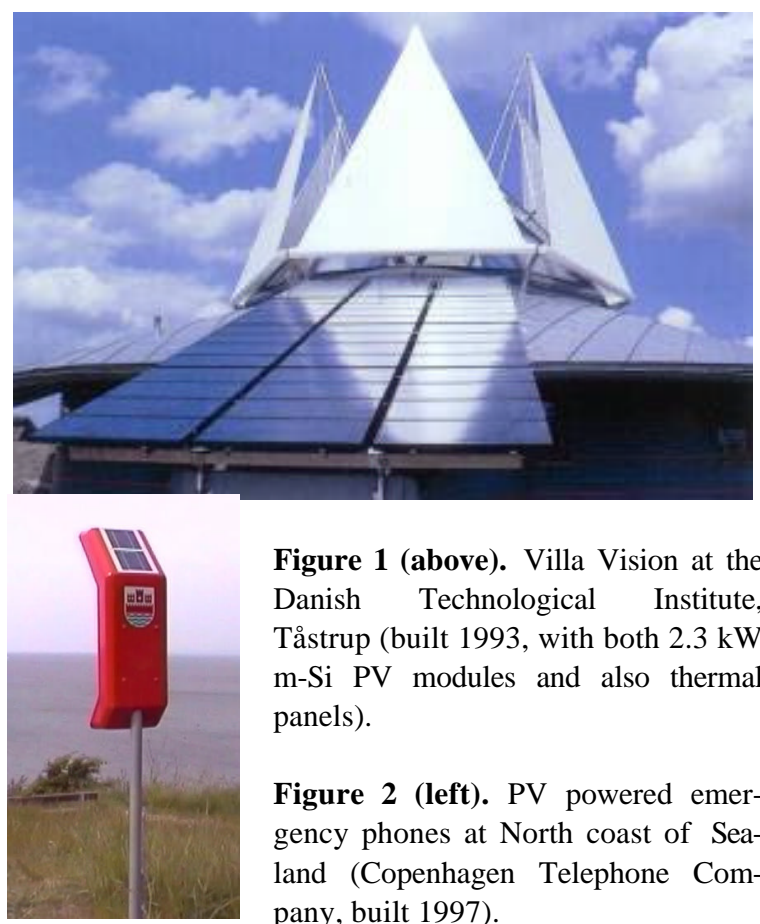

Figure 1 (above). Villa Vision at the Danish Technological Institute, Tåstrup (built 1993, with both $2.3 \mathrm{~kW}$ $\mathrm{m}$-Si PV modules and also thermal panels).

Figure 2 (left). PV powered emergency phones at North coast of Sealand (Copenhagen Telephone Company, built 1997). 


\section{RESEARCH AND INDUSTRY PARTNERSHIP}

The Danish Technological Institute showed an early interest in PV, resulting in the creation of a centre for information, testing of products and development assistance $f$ fered to industry. With some additional partners, this lead to the formation of a "Danish Solar Energy Centre". PV activity areas include

- Dye-sensitised cells

- PV/T system development

- Building-integrated components

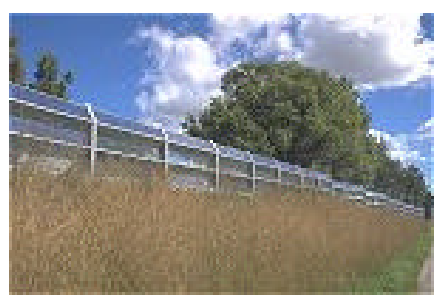

Figure 3 (left). PV panels mounted on road protection barrier at Fløng (NESA, built 1999).

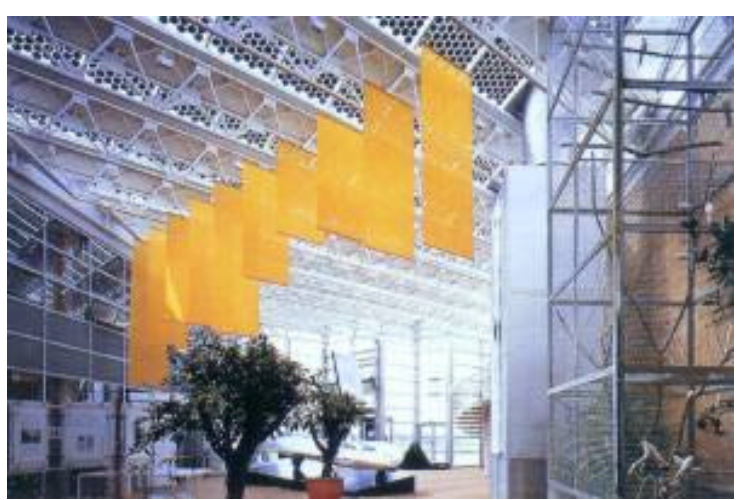

Figure 4 and 5. Brundtland Conference Centre in Toftlund (14 kW c-Si in roof and facade, built 1995). Interior (above) and outside view (below).

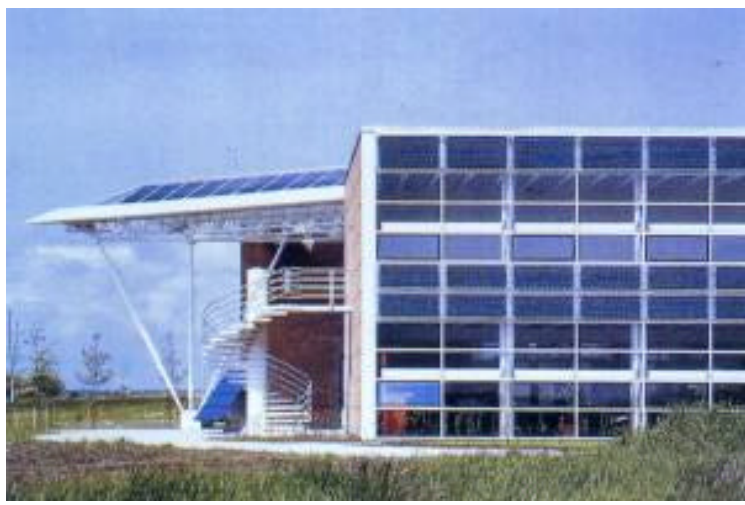

The testing and certification of solar products can develop into an advantageous synergism in product development, as it happened with the early collaboration between the Danish wind industry and the Wind Turbine Test Station near Roskilde. This has not quite happened in the solar case yet, perhaps because the solar industry (and particularly the solar thermal industry) has been less open to sharing bad as well as good experiences. The meticulous public dissemination of fault data from the Danish wind in- dustry and its customers was essential in rapidly improving the product quality. The solar industry, on the other hand, seemed more interested in keeping problem information away from marketplace exposure, and the removal of technical problems consequently progressed more slowly. The new generation of players in the field may ave a better understanding of the value of sharing experiences, at least during the first phases of development.

\section{DEMONSTRATION ISSUES}

Like in many other countries, the first demonstration projects in Denmark often had the flavour of plastering a solar cell panel on top of some building, with little attempt of integration or architectural considerations. Later, the importance of solar architecture and product integration has moved to the forefront (ळørensen, 1995), although the number of Danish architects educated in design of renewable energy systems is still exceedingly small. Energy basics were taught at the architecture schools for a few years during the mid-1970ies, and then removed. As a result, many architects still produce designs with miserable energy balances, if not North-facing solar panels, etc. Notable exceptions are the buildings shown in Figures 1, 4 and 5.

Danish building traditions have in the recent half century developed in the direction of accepting the cheapest possible raw buildings, but combined with large efforts to make the indoor decor as attractive as possible (a natural attitude in countries where people spent a large fraction of their time indoors, for climatic reasons). It is possible, that integration of solar energy devices into the building structure will heighten the concern over outside appearances, which would be a very positive contribution from solar energy.

Similarly, the recent interest in integrated solar products, which are strongly favoured in calls for public project support, has produced a lot of imaginative ideas, including (as it should be in this early phase) some doubtful concepts. Figures 2 and 3 show examples of taking advantage of off-grid PV opportunities, while Figure 6 shows a set of multicrystalline cell areas incorporated into a facade glass. In buildings where the architect uses huge glass facades in order to make the interior light and hot, the non-transparent PV may be a good idea, but for most buildings, the PV glass facade will just be replacing insulated walls, as the window area is already prescribed by building codes aiming at securing light penetration, to which the PV panels do not contribute, and thus the net energy gain by replacing an insulated wall by PV panels may well be zero (Sørensen, 2000b).

Denmark has used some of its modest public PV support money quite wisely, e.g. by establishing $30 \mathrm{PV}$ houses at a location where they could all be connected to the same power substation, and hence give valuable answers on stability of large-penetration PV systems (Kristensen et al., 1999). A recent new project of this type entails is equipping 300 houses with PV panels, the locations being spread over a dozen villages (Encon, 2000, see Figure 7). 


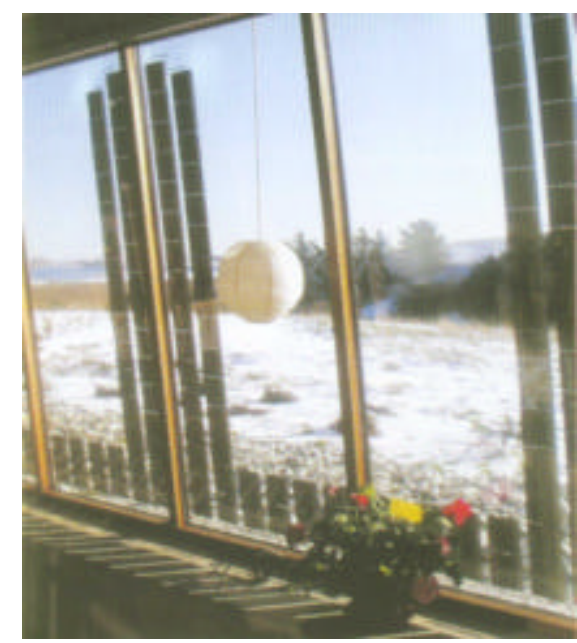

Figure 6.

Window integrated c-

$\mathrm{Si}$ and $\mathrm{m}-\mathrm{Si}$ solar cells at Skibstrup conference building (Midtglas, Gaia Solar, Peoples Renewable Energy Centre, built 2000)
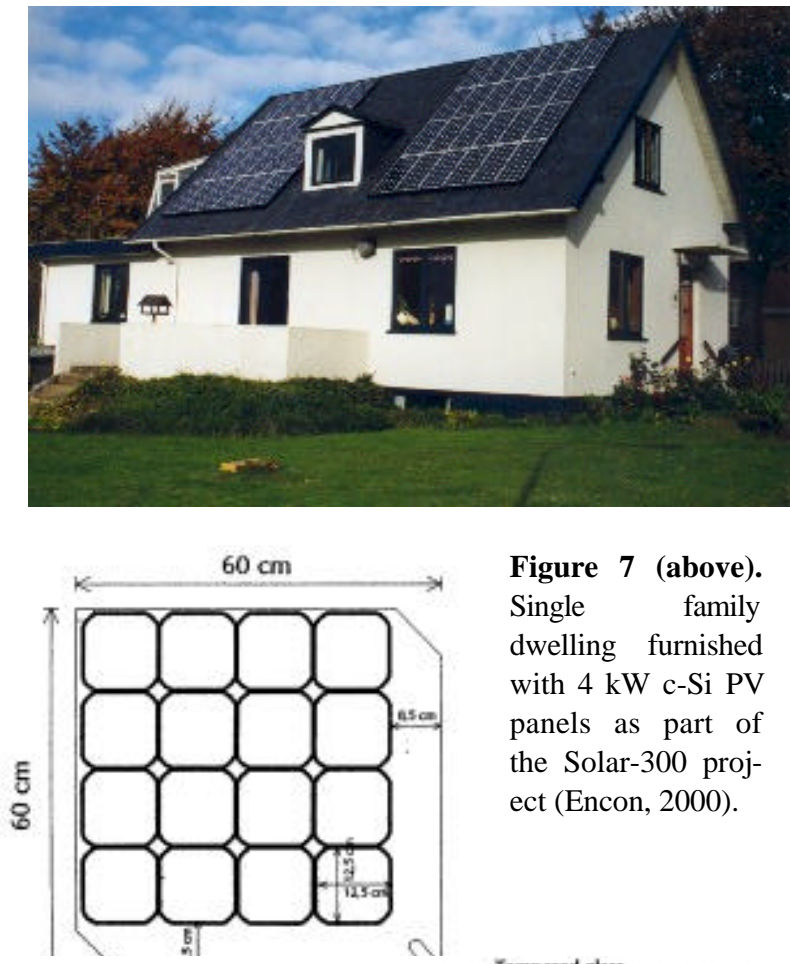

Figure 7 (above). Single family dwelling furnished with $4 \mathrm{~kW}$ c-Si PV panels as part of the Solar-300 project (Encon, 2000).

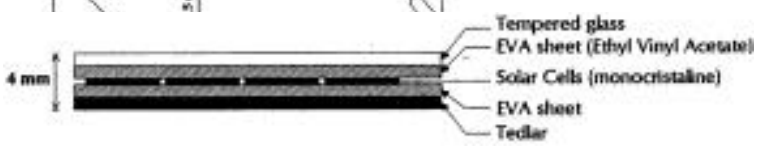

Figure 8. Prototype "Sunslate" shingle to be used in Skovlunde project (Dansk Eternit 2000).

The new round of projects receiving support in early 2000 includes an emphasis on using PV in the apartment buildings of Building Societies, of which many in Denmark are part of the co-operative tradition. An example is a large building block at Skovlunde, where the roof shingles have to be replaced. The company Dansk Eternit has developed a new shingle incorporating PV modules (Figure 8), which will be used in the retrofit. There is an additional possibil- ity of air cooling of the PV panel from the rear side, making this a PV-Thermal system (cf. Sørensen, 2000c).

Figure 9 shows an already completed apartment building renovation project incorporating PV panels in balconies, and Figure 10 a fringe project using PV on a hybrid luxury car, with plant oil diesel propulsion as its main source of energy.

\section{ORGANIC SOLAR CELLS}

The thinking behind this project is that organic solar cells (or photo-electrochemical cells, first suggested by O'Regan and Grätzel, 1991) might be more accessible for a country without any large microelectronics industry. Certainly the start costs are much lower than for production of PV cells, but the level of sophistication eventually characterising commercial organic solar cells is difficult to guess at this stage. Many other countries have started R\&D efforts in this field, and there is certainly work to do, as only a few hundred organic dye materials have been tested (and all of fairly similar structure). Also, the precise engineering of the anode $\mathrm{TiO}_{2}$ material is not yet fully optimised, and no suitable semiconductor cathode material has been found. $\mathrm{h}$ stead, an electrolyte Redox reaction with platinum catalyst is used, despite the much slower electron transport. Among the many alternatives considered are polymer electrode materials. This line of research (Bezzel et al., 2000) consumes about $15 \%$ of the recent addition to the Danish R\&D budget (by political request).

\section{CONCLUDING REMARKS}

The Danish experience may be relevant for other countries with a strong interest in renewable energy solutions and greenhouse gas emission reductions, but without the industrial basis required for full-scale indigenous production of all required PV devices and components. The programme adopted aims at establishing high value added component production, but based on international collaboration and providing systems containing a fair range of imported components, combined in innovative products.

This work is supported by the Danish Energy Agency. The author was chairman of the Agency's Solar Energy Committee during 1999.

\section{REFERENCES}

[1] Bezzel, E., Lauritzen, H., Wedel, S., West, K., Lund, T., Sørensen, F. and Sørensen, B., 2000. Development of building-integrated photo-electrochemical cell. Danish Energy Agency: Programme for Building-integrated Solar Cells, Contract 51181/00-0028.

[2] Encon, 2000. Webpage http://www.encon.dk/sol300

[3] Katic, I., Sørensen, B. and Windeleff, J., 1994. Danish National Photovoltaic Programme. pp. 2302-2305 in "1st World Conference on Photovoltaic Energy Conversion, Hawaii”, IEEE Electron Devices Soc., USA. 
[4] Katic, I., Sørensen, H. and Sørensen, B., 2000. Solar cell systems with combined power and heat production. Energy Research Programme EFP2000 of the Danish Energy Agency, Contract 1753/00-0014.

[5] Kristensen, P., Kristensen, F. and Ahm, P., 1999. Solbyprojektet. Final report (71pp). Encon, Brædstrup

[6] Leistiko, O., 1994. The waffle: a new photovoltaic diode geometry having high efficiency and backside contacts. pp. 1462-1465 in "1st World Conference on Photovoltaic Energy Conversion, Hawaii”, IEEE Electron Devices Society, USA

[7] Sørensen, B., 1995. Fotovoltaisk Statusnotat 3. Final Report for Danish Energy Agency Project 51181/940002

[8] Sørensen, B., 2000. Renewable Energy, 2nd Edition, 912 pp., Academic Press, London.

[9] Sørensen, B., 2000b. The future Solar Landscape. Talk presented at DANVAC Solar Energy Seminar, Danish Technological Institute, 7. March.

[10] Sørensen, B., 2000c. PV power and heat production; an added value (contribution to this conference).

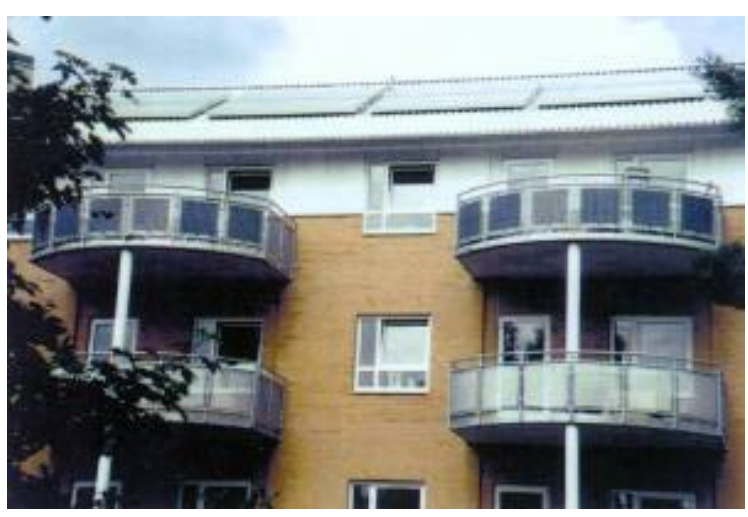

Figure 9 (above). Balcony PV retrofits in Herning (2kW c$\mathrm{Si}$, installed 1997).

Figure 10 (below). "Connector 2001" hybrid solar cellplant oil car (Toria, developed during mid-1990ies).

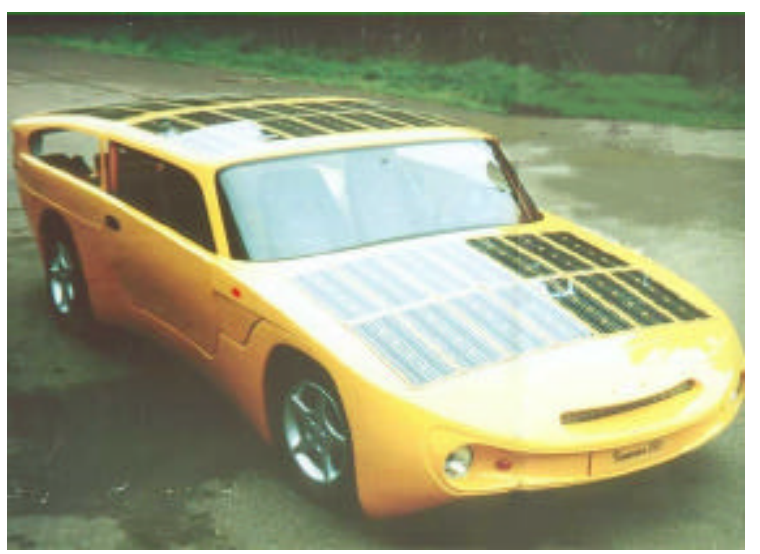

